\title{
Radzenie sobie ze stresem i samoocena słyszących ojców a głuchota dziecka
}

\section{Coping with stress and self-esteem of hearing fathers and child's deafness}

\author{
Joanna Kobosko \\ Instytut Fizjologii i Patologii Słuchu, Światowe Centrum Słuchu, Kajetany \\ Adres autora: Joanna Kobosko, Światowe Centrum Słuchu, ul. Mokra 17, Kajetany, 05-830 Nadarzyn, \\ e-mail: j.kobosko@ifps.org.pl
}

Streszczenie

Cel: W pracy postawiono pytanie, czy style radzenia sobie ze stresem i samoocena, a także związki zachodzące między nimi są u ojców modyfikowane przez głuchotę dziecka. Odwołano się do wiedzy klinicznej, z której wynika, że w głuchotę dziecka i jej rozliczne konsekwencje zostaje uwikłane przeżycie przez rodziców traumy wskutek jej stwierdzenia. Uwzględniono też płeć dziecka, wiek dziecka, a także czas upływający od momentu postawienia u dziecka diagnozy głuchoty.

Metoda: Badaniami objęto 53 słyszących ojców dzieci głuchych w wieku od 4 do 192 miesięcy oraz 43 ojców dzieci o prawidłowym rozwoju w podobnym wieku. Do pomiaru stylów radzenia sobie ze stresem wykorzystano Kwestionariusz Radzenia sobie w Sytuacjach Stresujących (CISS), a do opisu samooceny Skalę Samooceny Rosenberga (SES) w polskiej adaptacji.

\begin{abstract}
Wyniki: Okazało się, że ojcowie dzieci głuchych nie różnią się istotnie od ojców dzieci słyszących o typowym rozwoju w zakresie stosowanych stylów radzenia sobie ze stresem w sytuacjach trudnych, ani w posiadanej samoocenie. Nie wykazano związku między wymienionymi zmiennymi a czasem upływającym od momentu diagnozy u dziecka głuchoty oraz wiekiem i płcią dziecka. Uzyskano jedynie rezultat mówiący o tym, że wysoka samoocena ojców dzieci głuchych nie jest predyktorem zadaniowego stylu radzenia sobie ze stresem, jak ma to miejsce w przypadku ojców dzieci o typowym rozwoju. Ojcowie dzieci głuchych niezależnie od posiadanej samooceny deklarują zadaniowy styl radzenia sobie w sytuacji doświadczania stresu, co może wiązać się z głuchotą dziecka. Z jednej strony bowiem mogą podejmować się wielu zadań związanych z rehabilitacją dziecka (adaptacja), z drugiej zaś poszukują sposobu, jakim może być nadmiarowa aktywność ukierunkowana na realizację zadań (psychiczna obrona), aby odciąć się od przeżyć związanych z byciem ojcem głuchego dziecka.
\end{abstract}

Wnioski: Istnieje konieczność dalszych badań nad psychologicznym funkcjonowaniem ojców dzieci głuchych.

Słowa kluczowe: styl radzenia sobie ze stresem • samoocena • głuchota dziecka• ojciec dziecka głuchego

Abstract

Aim: This study addresses the question does the deafness of a child modify its father's stress coping styles and self-esteem, and relations occurring between these two traits. Author referred to the clinical knowledge that child's deafness and its numerous consequences become tied with parents' trauma caused by the diagnosis of deafness. Study took into account child's sex, age and time elapsed since the diagnosis of deafness.

Method: Study included 53 hearing fathers of deaf children (children's age between 4 and 192 months) and 43 fathers of typically developing children in similar ages. Assessment of the stress coping styles had been performed using the Coping Inventory for Stressful Situations (CISS), and the self-esteem using the Rosenberg's Self-Esteem Scale (SES) in Polish adaptation.

Results: It turned out that fathers of deaf children are not significantly different from fathers of typically developing children in so far as to their styles of coping with stress in difficult situations and self-esteem. No relation between these variables and time elapsed from the diagnosis of deafness, child's age and sex was shown. The only outcome obtained showed that the high self-esteem of fathers of deaf children is not a predictor for the task-oriented stress-coping style, as it is in the case of fathers of normally developing children. Fathers of deaf children, independent of their self-esteem, declare task-oriented style of coping with stress, which may be related to their child's deafness. This is because on one hand they may undertake many tasks 
related to the child's rehabilitation (adaptation), on the other, they are looking for a way to distance themselves from feelings related to being a father of a deaf child, and the excessive task oriented activity may be such a way (psychological defense).

Conclusions: It is necessary to continue the research on the psychological functioning of fathers of deaf children.

Key words: stress-coping style • self-esteem • child's deafness $\bullet$ father of a deaf child

\section{Wprowadzenie}

Badania nad ojcami dzieci głuchych ${ }^{1}$ stanowią zdecydowaną mniejszość w nurcie badań nad psychologicznymi aspektami rodzicielstwa matek i ojców dziecka głuchego, jak i jego związku z rozwojem dziecka. Można powiedzieć, że praktycznie nie istnieją. Badacze nawet jeśli uwzględniają ojców dzieci głuchych w swoich projektach badawczych, stanowią oni co najwyżej do $20 \%$ badanych rodziców [np. Jackson, 2011], a ze względu na znikomą liczebność - jak się można domyślać - wyniki ojców nie są oddzielnie analizowane, jak i bywa, że zostają pominięte. Niejednokrotnie mamy do czynienia ze zjawiskiem nadmiernego uogólniania, a więc pojawia się kategoria „rodzice" bez dokonywania rozróżnienia, czy chodzi o matkę czy o ojca dziecka, np. dotyczy to badań, w których rodzice, matka lub/i ojciec dokonują oceny zachowań dziecka albo wypowiadają się na temat efektywności programów wczesnej interwencji. W dokonanym przeglądzie artykułów, które ukazały się w latach 2002-2011 na temat „rodzicielstwa dziecka głuchego" w trzech prestiżowych czasopismach poświęconych Deaf Studies: American Annals of the Deaf, The Volta Review i Journal of Deaf Studies and Deaf Education, nie znalazł się ani jeden tekst dotyczący samych ojców (tekst taki pojawił się dopiero w 2012 roku w czasopiśmie American Annals of the Deaf - zob. Ingber, Most, 2012), zaledwie kilka dotyczyło zarówno matek, jak i ojców dzieci głuchych, zaś większość prac w omawianym obszarze poświęconych zostało wyłącznie matkom dzieci głuchych. Nietrudno się domyślić, iż nie istnieją badania nad ojcami głuchymi, wychowującymi dzieci głuche lub/i dzieci słyszące, które byłyby opublikowane na łamach wymienionych czasopism.

Opisany powyżej stan badań nad ojcami dzieci głuchych stanowi w pewnym sensie odzwierciedlenie sytuacji dotyczącej badań nad ojcami dzieci w normie rozwojowej oraz dzieci z różnymi zaburzeniami rozwojowymi i chorobami przewlekłymi. Jak relacjonuje Phares i współpracownicy (2005), którzy dokonali przeglądu 17 czasopism publikowanych na świecie w latach 1996-2003, dotyczących zarówno dziedziny pediatrii i zdrowia, jak i niezwiązanych z tymi dziedzinami, tekstów dotyczących wyłącznie ojców wyodrębniono 14 , co stanowi 3\% wszystkich opublikowanych w tych czasopismach artykułów na temat rodziców.

Dowiedziono naukowo, że ojciec pełni ważną rolę dla rozwoju dziecka. Ojcowie mają wpływ na rozwój dziecka niemalże we wszystkich sferach: społecznej i intelektualnej, językowej czy związanej z osiągnięciami szkolnymi, a nawet wykazano związek ojców ze zdrowiem fizycznym dzieci [Lamb, 2004; Tamis-LeMonda, Cabrera, 2002; za:
Phares i wsp., 2005]. Wiadomo też o związkach psychologicznego funkcjonowania ojców i dzieci z zaburzeniami w rozwoju, m.in. o tym, że obecność symptomów psychopatologicznych u ojców stanowi czynnik ryzyka rozwoju problemów emocjonalnych i behawioralnych u dzieci. Badacze mówią o licznych podobieństwach, ale i różnicach w psychologicznym funkcjonowaniu rodziców obu płci [Phares i wsp., 2005].

W artykule skoncentrowano się na dwóch obszarach psychologicznego funkcjonowania słyszących ojców dzieci głuchych, do jakich należy radzenie sobie ze stresem (style radzenia sobie) oraz samoocena. Przyjęto, iż głuchota dziecka może modyfikować sposób radzenia sobie ze stresem i samoocenę ojców, a także relacje między nimi, z tego między innymi względu, że doświadczyli oni traumy wskutek stwierdzenia u dziecka głuchoty [Kurtzer-White, Luterman, 2003; Zalewska, 1998a, 1998b], jak i jej licznych konsekwencji.

\section{Radzenie sobie ze stresem w koncepcji N. S. Endlera i J. C. D. Parkera}

W psychologii stresu sposoby, w jaki ludzie radzą sobie ze stresem, uważa się za zagadnienie ważniejsze niż samo nasilenie doświadczanego stresu [Ogińska-Bulik, Juczyński, 2010]. Styl radzenia sobie określa się jako pewną dyspozycję osoby do reagowania w sytuacji stresującej w określony sposób bądź, jak czyni to Heszen-Niejodek, ujmuje się jako „będący w dyspozycji osoby i charakterystyczny dla niej zbiór strategii czy sposobów radzenia sobie, z których część uruchamiana jest w procesie radzenia sobie z konkretną konfrontacją stresową" [za: Sekułowicz, Sipiorski, 2009, s. 445].

Badacze Endler i Parker (1994), nawiązując do koncepcji interakcyjnej stresu Lazarusa i Folkman, wyróżniają 3 style radzenia sobie: 1) styl skoncentrowany na zadaniu, polegający na podejmowaniu wysiłków mających na celu rozwiązanie problemu przez próby zmiany sytuacji lub dokonywanie przekształceń poznawczych; 2) styl skoncentrowany na emocjach, charakteryzujący się koncentracją na własnych przeżyciach i emocjach; wiąże się on $\mathrm{z}$ fantazjowaniem i myśleniem życzeniowym, mającym na celu obniżenie napięcia emocjonalnego oraz 3) styl skoncentrowany na unikaniu, polegający na przejawianiu tendencji do wystrzegania się myślenia, przeżywania i konfrontowania się z sytuacją stresową, bądź w formie angażowania się w czynności odwracające uwagę od problemu (np. oglądanie telewizji, jedzenie), bądź w formie poszukiwania kontaktów towarzyskich, po to, by obniżyć towarzyszące mu napięcie [Endler, Parker, 1994; Strelau i wsp., 2009].

\footnotetext{
1. Określenie „dziecko głuche” obejmuje dzieci, które wg klasyfikacji audiologicznych (np. BIAP) posiadają znaczny lub głęboki ubytek słuchu, co odpowiada przyjętemu w naukach społecznych definiowaniu osoby głuchej jako tej, która bez urządzeń wzmacniających słyszenie nie odbiera przy uchu głośnej mowy, a więc jest głucha (ang. deaf).
} 
Za najbardziej przystosowawczy sposób radzenia sobie ze stresem badacze ci uznają styl skoncentrowany na zadaniu, w którym ma miejsce aktywne podejście do problemu. Styl zadaniowy jest skorelowany z ekstrawersją i inteligencją emocjonalną, co sugeruje pozytywne możliwości afektywnej regulacji i adaptacji także do wydarzeń traumatycznych. Styl unikający, jak wskazują różni badacze [Endler, Parker, 1994; Hatchett, Park, 2004], gdy stosuje się go przez krótki czas, może być równie efektywny, gdyż wiąże się m.in. z przeżywaniem (doraźnie) pozytywnego nastroju. Angażowanie się w czynności zastępcze jako jedna $\mathrm{z}$ form unikania koreluje dodatnio $\mathrm{z}$ poziomem lęku u osób z depresją [McWilliams, Cox, Enns, 2003]. Z kolei styl skoncentrowany na emocjach pozostaje w związ$\mathrm{ku} \mathrm{z}$ symptomami psychopatologicznymi, np. depresją [Endler, Parker, 1990; Hatchett, Park, 2004; McWilliams, Cox, Enns, 2003], jak i zazwyczaj wskazuje na intensyfikację doświadczanego stresu, choć może spełniać także pozytywną rolę, np. w początkowym okresie doświadczania przez osobę traumy, gdzie konfrontacja z emocjami i wyrażenie emocji stanowią jeden $\mathrm{z}$ warunków jej przepracowania [Lis-Turlejska, 2004]. Endler i Parker (1994) są zdania, że sposób reakcji na doświadczany stres może być różny u tego samego człowieka zależnie od rodzaju sytuacji trudnej.

\section{Style radzenia sobie ze stresem ojców dzieci niepełnosprawnych}

Style radzenia sobie ze stresem, a tym samym $\mathrm{z}$ niepełnosprawnością dziecka, są przedmiotem badań w zdecydowanej większości dotyczących rodziców dzieci z niepełnosprawnością inną niż głuchota. $Z$ badań tych wynika, że rodzice dzieci z zaburzeniami rozwojowymi częściej stosują unikający sposób radzenia sobie ze stresem niż rodzice dzieci o typowym rozwoju [np. Margalit, Raviv, Ankonina, 1992]. Ojcowie niejednokrotnie przez koncentrację na instrumentalnej stronie sytuacji, będącej wynikiem niepełnosprawności dziecka, „unikają kontaktu z własnym bolesnym poczuciem straty i obniżoną oceną siebie" [za: Wiktorowicz, 2006, s. 7].

Odmienne rezultaty w zakresie stylów radzenia sobie ze stresem, stosowanych przez matki i ojców dzieci z autyzmem, zespołem Downa i dzieci o typowym rozwoju w wieku od 2 do 6 lat, otrzymano w badaniach Dąbrowskiej i Pisuli (2010). Wynika z nich coś przeciwnego, a mianowicie, że jedynie ojców (i matki) dzieci z autyzmem cechuje niższe nasilenie stylu unikającego, polegającego na poszukiwaniu kontaktów towarzyskich, względem dwóch pozostałych grup. $Z$ kolei ojcowie dzieci z mózgowym porażeniem dziecięcym w wieku od 3 do 7 lat w porównaniu $\mathrm{z}$ ojcami dzieci o typowym rozwoju nie różnili się stylami radzenia sobie ze stresem w sytuacjach trudnych [Parchomiuk, 2007].

Sposoby radzenia sobie $\mathrm{z}$ napięciem i stresem, doświadczanym w związku z ojcostwem dziecka niepełnosprawnego, ulegają zmianom wraz z wiekiem dziecka - rodzice starszych dzieci częściej niż rodzice dzieci młodszych unikają konfrontacji ze stresem [Pisula, Rola, Wąsiewicz-Pawłowska, 1994; za: Pisula, 2007], przejawiają większą rezygnację, nie dążą do zmian [Grant, Whittel, 2000; za: Pisula, 2007]. Style radzenia sobie ze stresem stosowane przez słyszące matki i ojców dzieci głuchych i słabosłyszących były przedmiotem wcześniejszych badań autorki [Kobosko, 2011], a ojcowie uzyskali w nich wyniki mówiące o ich przeciętnym nasileniu w odniesieniu do norm dla populacji polskiej. W sytuacjach trudnych ojcowie dzieci głuchych i słabosłyszących rzadziej stosują styl skoncentrowany na emocjach w porównaniu $\mathrm{z}$ matkami, co jest zgodne z normami dla kobiet i mężczyzn. Ojcowie również istotnie rzadziej preferują styl unikający w jego dwóch odmianach, tj. w formie poszukiwania kontaktów towarzyskich, jak i angażowania się w czynności zastępcze.

Podejmowane przez rodziców dzieci z różnymi zaburzeniami rozwojowymi sposoby radzenia sobie ze stresem pozostają także w związku z etapami procesu żałoby, będącej reakcją psychiczną rodzica przeżywaną wskutek utraty dziecka zdrowego, normalnego na rzecz dziecka niepełnosprawnego [Zalewska, 1998a, 1998b]. W związku z tym inaczej radzić sobie będą ci ojcowie, którzy zaprzeczają rzeczywistości, w tym niepełnosprawności dziecka, a inaczej ojcowie będący w stanie depresji. Stwierdzono, że ojcowie dzieci głuchych wykazują istotnie silniejszą tendencję do zaprzeczania przeżyciom związanym z głuchotą dziecka niż matki [Anagnostou, Graham, Crocker, 2007]. Trzeba też brać pod uwagę duże zróżnicowanie indywidualne właściwości reagowania ojców, zarówno jeśli chodzi o czas trwania, intensywność, jak i przebieg poszczególnych faz procesu żałoby.

\section{Samoocena ojców dzieci niepełnosprawnych}

Samoocena to zdaniem Rosenberga [za: Dzwonkowska, Lachowicz-Tabaczek, Łaguna, 2009] emocjonalna reakcja na własną osobę. Pomimo że brak jest badań na ten temat w odniesieniu do ojców dzieci niepełnosprawnych, można o ich samoocenie wnioskować na podstawie wyników badań, które wskazują na problemy ze zdrowiem psychicznym. Należą do nich np. zaburzenia depresyjne obecne u ojców dzieci z upośledzeniem umysłowym [np. Olsson, Hwang, 2001], choć wyniki badań nie są w tej kwestii jednoznaczne. Można więc sądzić, że ojców dzieci niepełnosprawnych z objawami zaburzeń depresyjnych charakteryzuje negatywny obraz siebie w różnych sferach, co wiąże się z negatywnymi emocjami wokół własnej osoby. W badaniach Zaczyńskiej (1999) słyszący ojcowie dzieci głuchych odznaczali się podobnym poziomem depresyjności co ojcowie dzieci słyszących o prawidłowym rozwoju, jednakże różnili się, gdy uwzględniono ich sposób komunikowania się z dzieckiem głuchym. Ciekawe, że większe nasilenie depresyjności było obecne u tych ojców, którzy porozumiewali się z dzieckiem głuchym w języku fonicznym, w porównaniu $\mathrm{z}$ tymi, którzy wybrali manualny sposób komunikowania się ze swoim głuchym dzieckiem, tj. język migowy.

Ojców dzieci z mózgowym porażeniem dziecięcym w wieku od 3 do 7 lat badała Parchomiuk (2007). W zakresie większości ocenianych przez tę autorkę wymiarów samooceny ojcowie ci uzyskali podobne wyniki do ojców dzieci pełnosprawnych, jak i cechowało ich pozytywne nastawienie do siebie: ojcowie $\mathrm{z}$ obu grup akceptowali siebie, wierzyli we własne możliwości i posiadali poczucie własnej wartości - jednakże nieco bardziej pozytywne nastawienie prezentowali ojcowie dzieci pełnosprawnych, 
Tabela 1. Wykształcenie ojców dzieci głuchych i ojców dzieci słyszących o prawidłowym rozwoju według wyodrębnionych kategorii: wykształcenie podstawowe, średnie, niepełne wyższe i wyższe

\begin{tabular}{ccccc}
\hline Ojcowie & \multicolumn{3}{c}{ Wyksztatcenie } \\
\cline { 2 - 5 } & Podstawowe & Średnie & Niepełne wyższe & Wyższe \\
\hline $\begin{array}{c}\text { Ojcowie dzieci głuchych } \\
(\mathrm{n}=53 \text {; brak danych }-1)\end{array}$ & 3 & 21 & 5 & 23 \\
\hline $\begin{array}{c}\text { Ojcowie dzieci styszących } \\
(\mathrm{n}=43 ; \text { brak danych }-2)\end{array}$ & 0 & 11 & 3 & 27 \\
\hline
\end{tabular}

którzy jednocześnie przypisywali sobie więcej cech pozytywnych. Zdaniem autorki cytowanych badań uzyskane rezultaty pozwalają wnioskować, że u ojców dzieci z mózgowym porażeniem dziecięcym występuje znacząco większa tendencja do zaprzeczania cechom negatywnym w obrazie swojego ,ja”.

W wielu badaniach wykazano, że samoocena jest moderatorem tego, jak człowiek radzi sobie w sytuacjach stresujących, a także tego, jakie style radzenia sobie ze stresem stosuje [za: Terelak, 2008].

\section{Cel badań}

Celem podjętych badań była odpowiedź na pytanie, czy słyszący ojcowie dzieci głuchych różnią się stylami radzenia sobie ze stresem stosowanymi w sytuacjach trudnych, a także samooceną $\mathrm{w}$ porównaniu $\mathrm{z}$ ojcami dzieci o typowym rozwoju. W badaniach uwzględniono płeć i wiek dziecka, a w przypadku ojców dzieci głuchych upływ czasu od momentu diagnozy głuchoty u dziecka. Postawiono następujące pytania badawcze:

- Czy ojcowie dzieci głuchych różnią się stosowanymi stylami radzenia sobie ze stresem i samooceną od ojców dzieci słyszących o typowym rozwoju?

- Czy style radzenia sobie ze stresem i samoocena ojców dzieci głuchych i dzieci słyszących o typowym rozwoju pozostają w związku z wiekiem i płcią dziecka?

- Czy style radzenia sobie ze stresem i samoocena ojców dzieci głuchych pozostają w związku z upływem czasu od momentu stwierdzenia u dziecka głuchoty?

- Czy istnieje związek między stylami radzenia sobie ze stresem i samooceną ojców dzieci głuchych i dzieci słyszących? Czy samoocena może być predyktorem stylów radzenia sobie ze stresem stosowanych w obu grupach ojców?

\section{Metody badań}

Osoby badane

W badaniach wzięło udział 53 słyszących ojców dzieci głuchych bez dodatkowych niepełnosprawności, a także 43 ojców dzieci słyszących o typowym rozwoju. Dzieci ojców z grupy właściwej, które posiadały uszkodzenie narządu słuchu w lepszym uchu odpowiadające zgodnie z klasyfikacją audiologiczną BIAP znacznemu (70-90 dB) ubytkowi słuchu, stanowiły $20,8 \%$, pozostałe to dzieci o ubytku słuchu w stopniu głębokim (ubytek słuchu powyżej 90 dB). Średnia wieku dzieci głuchych mierzonego w miesiącach wynosiła: $M=76,17 ; S D=46,77$, a w grupie dzieci słyszących: $M=69,3 ; \mathrm{SD}=47,11$. W odniesieniu do wieku ojców dzieci głuchych otrzymano średnią mierzoną w latach: $\mathrm{M}=37,19 ; \mathrm{SD}=5,98$, a dla wieku ojców dzieci słyszących średnia ta wyniosła: $M=36,05 ; S D=5,32$. Wiek ojców i ich dzieci z obu grup jest wyrównany. Wśród dzieci głuchych dziewczynki stanowiły $43,4 \%$, chłopcy $54,7 \%$, natomiast w grupie dzieci słyszących znalazło się 48,8\% dziewczynek i 46,5\% chłopców. W związku małżeńskim z matką dziecka głuchego pozostawało $88,7 \%$ ojców, a $\mathrm{z}$ matka dziecka słyszącego $88,4 \%$. Wykształcenie ojców przedstawiono w Tabeli 1.

Wśród dzieci głuchych, których ojcowie uczestniczyli w badaniach, aż 47 dzieci $(88,7 \%)$ korzysta $\mathrm{z}$ implantu ślimakowego, pozostałe sa użytkownikami konwencjonalnych aparatów słuchowych. W prezentowanych badaniach stanowią one jedną grupę, gdyż jak zostało dowiedzione $\mathrm{w}$ licznych badaniach dotyczących rodziców dzieci głuchych, typ protezy słuchowej, tj. konwencjonalny aparat słuchowy v. implant ślimakowy, z jakiej korzysta dziecko głuche, nie pozostaje w związku z psychicznym funkcjonowaniem rodziców [m.in. Asberg, Vogel, Bowers, 2008; Kobosko, 2011]. Wiek dzieci w momencie stwierdzenia ubytku słuchu wynosił średnio 11 miesięcy $(\mathrm{M}=11,31 ; \mathrm{SD}=13,9)$

\section{Narzędzia badawcze}

W badaniach wykorzystano Kwestionariusz Radzenia sobie w Sytuacjach Stresujących (CISS) w polskiej adaptacji autorstwa Strelaua i współpracowników (2009), Skalę Samooceny M. Rosenberga (SES) w polskiej adaptacji Dzwonkowskiej, Lachowicz-Tabaczek i Łaguny (2008) oraz Ankietę informacyjną własnej konstrukcji. Wskaźniki zgodności wewnętrznej $\alpha$ Cronbacha otrzymane w relacjonowanych badaniach dla zastosowanych narzędzi badawczych zostały zawarte w Tabeli 2.

Kwestionariusz Radzenia sobie w Sytuacjach Stresujących (CISS) (Coping Inventory for Stressful Situations Endler, Parker, 1994). Kwestionariusz CISS przeznaczony jest do oceny stylów radzenia sobie ze stresem. Składa się z 48 pozycji, na które odpowiada się na 5-punktowej skali typu Likerta: 1 - oznacza nigdy, 2 - bardzo rzadko, 3 czasami, 4 - często, 5 - bardzo często. Narzędzie to służy do pomiaru 3 stylów radzenia sobie ze stresem: stylu skoncentrowanego na zadaniu (skala SSZ - np. Koncentruje sie na problemie i zastanawiam się, jak moge go rozwiązać), stylu skoncentrowanego na emocjach (skala SSE - np. Niepokoję się, że sobie nie poradze) i stylu skoncentrowanego na unikaniu (skala SSU) w dwóch odmianach: angażowanie się w czynności zastępcze (podskala ACZ np. Objadam się ulubiona potrawa) oraz poszukiwanie 
Tabela 2. Wskaźniki zgodności wewnętrznej $\alpha$ Cronbacha uzyskane dla zastosowanych narzędzi badawczych

\begin{tabular}{llc}
\hline \multicolumn{1}{c}{ Nazwa kwestionariusza } & $\begin{array}{c}\text { Ojcowie dzieci głuchych } \\
\text { Wskaźnik } \alpha \text { Cronbacha }\end{array}$ & $\begin{array}{c}\text { Ojcowie dzieci słyszących } \\
\text { Wskaźnik } \alpha \text { Cronbacha }\end{array}$ \\
\hline Kwestionariusz Radzenia sobie & & \\
w Sytuacjach Stresujących & & 0,881 \\
(CISS - Endler, Parker, 1994) & & 0,882 \\
Styl Skoncentrowany na Zadaniu (SSZ) & 0,830 & 0,847 \\
Styl Skoncentrowany na Emocjach (SSE) & 0,857 & 0,616 \\
Styl Skoncentrowany na Unikaniu (SSU) & 0,871 & 0,803 \\
Poszukiwanie Kontaktów Towarzyskich (PKT) & 0,793 & 0,852 \\
Angażowanie się w Czynności Zastępcze (ACZ) & 0,828 & 0,828 \\
\hline Skala Samooceny Rosenberga & & 0,792 \\
(SES - Rosenberg, 1965) & & \\
\hline
\end{tabular}

kontaktów towarzyskich (podskala PKT- np. Staram się przebywać z innymi ludźmi). Do każdego stylu radzenia sobie ze stresem przypisanych jest 16 pozycji, a wynik w odniesieniu do każdego stylu mieści się w przedziale od 16 do 80 punktów. Im wyższy wynik dla danego stylu, tym częściej osoba badana posługuje się strategiami wchodzącymi w jego skład.

Skala Samooceny (SES) (Self-Esteem Scale - Rosenberg, 1965; za: Dzwonkowska, Lachowicz-Tabaczek, Łaguna, 2008) służy do pomiaru poziomu samooceny globalnej, na którą składa się emocjonalna reakcja na siebie oraz poczucie kompetencji, rozumianej zarówno jako cecha, jak i jako stan. Dlatego też SES może być stosowana do oceny zmian zachodzących w omawianej sferze, także w odpowiedzi na pojawiajace się wydarzenia. Skala samooceny SES składa się z 10 twierdzeń (np. Potrafię robić różne rzeczy tak dobrze, jak większość innych ludzi czy Ogólnie rzecz biorac, jestem $z$ siebie zadowolony), na które badani udzielają odpowiedzi na czterostopniowej skali od $1-z$ decydowanie zgadzam się do 4 - zdecydowanie nie zgadzam się, uzyskując za każdą odpowiedź od 1 do 4 punktów. Czas odpowiedzi jest nieograniczony, średnio wynosi od 2 do 5 minut. Wynik ogólny stanowi suma punktów; im jest ona wyższa, tym wyższy ogólny poziom samooceny posiada dana osoba. Badany może uzyskać od 10 do 40 punktów.

Ankieta informacyjna zawiera pytania dotyczące płci, wieku, wykształcenia i statusu małżeńskiego rodzica, który uczestniczył w badaniach, a także płci, wieku i stanu zdrowia dziecka. Ojcowie dzieci głuchych podawali dane odnośnie wieku dziecka w momencie stwierdzenia u niego głuchoty (niedosłuchu) i stopnia ubytku słuchu. W Ankiecie pytano też o to, czy dziecko korzysta $\mathrm{z}$ konwencjonalnych aparatów słuchowych czy z implantu (implantów) ślimakowego.

\section{Procedura badań}

Prezentowane badania stanowią fragment szerszego projektu badawczego dotyczącego psychologicznego funkcjonowania rodziców dzieci głuchych realizowanego w ramach działalności statutowej Instytutu Fizjologii i Patologii Słuchu (IFPS) w latach 2011-2012. Badani rodzice otrzymywali zestawy kwestionariuszy do wypełnienia i list wyjaśniający naukowy cel badań, a także informujący o anonimowości pozyskanych informacji. Badania ojców dzieci głuchych prowadzono podczas turnusów rehabilitacyjnych

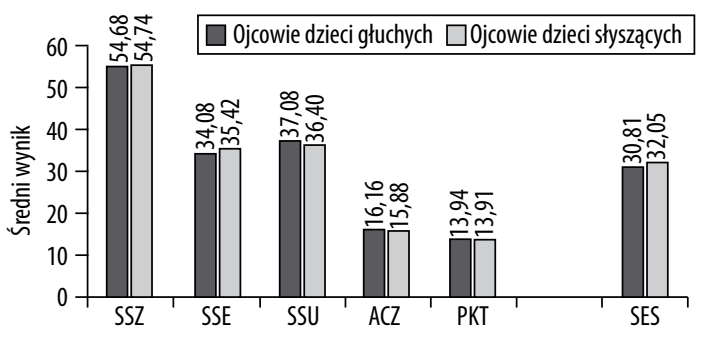

Rycina 1. Style radzenia sobie ze stresem i samoocena - wyniki uzyskane w Kwestionariuszu CISS (Styl Skoncentrowany na Zadaniu - SSZ; Styl Skoncentrowany na Emocjach - SSE; Styl Skoncentrowany na Unikaniu - SSU wraz z podskalami: Angażowanie się w Czynności Zastępcze - ACZ i Poszukiwanie Kontaktów Towarzyskich - PKT) oraz w Skali Samooceny Rosenberga SES w grupie ojców dzieci głuchych i ojców dzieci słyszących o prawidłowym rozwoju (średnie)

oraz pobytów z dzieckiem na hospitalizacjach w Klinice Rehabilitacji IFPS, a także w wybranych ośrodkach diagnozy i rehabilitacji z całej Polski. W związku z przyjętą procedurą badań rodzice zwracali osobie przeprowadzającej badania wypełnione kwestionariusze w zaklejonych kopertach. Do obliczeń statystycznych wyników badań wykorzystano: test chi-kwadrat, test t-Studenta, test Kruskalla-Wallisa, test U-Manna-Whitneya, korelację r Pearsona i analizę regresji liniowej.

\section{Wyniki}

Style radzenia sobie ze stresem ojców a głuchota dziecka

W sytuacjach trudnych ojcowie dzieci głuchych stosują wszystkie wyodrębnione $\mathrm{w}$ badaniu style radzenia sobie ze stresem, tj. styl skoncentrowany na zadaniu, styl skoncentrowany na emocjach, a także styl unikający, polegający zarówno na poszukiwaniu kontaktów towarzyskich, jak i podejmowaniu czynności zastępczych, w nasileniu podobnym do ojców dzieci słyszących o prawidłowym rozwoju. Nie stwierdzono między ojcami z obydwu grup różnic istotnych statystycznie ze względu na zmienną, jaką jest głuchota dziecka (Rycina 1). 


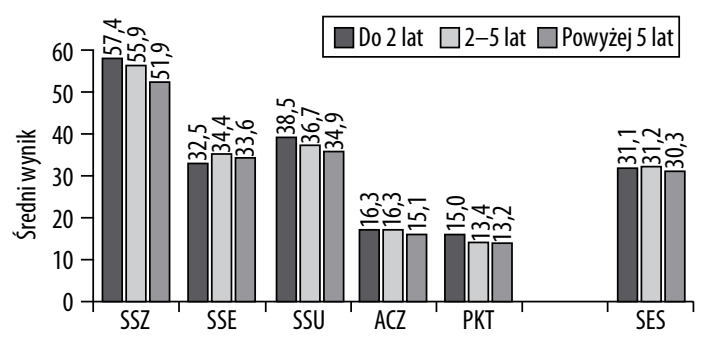

Rycina 2. Czas od momentu stwierdzenia głuchoty u dziecka (do 2 lat, $>2$ lat do 5 lat, $>5$ lat) a style radzenia sobie ze stresem i samoocena - wyniki uzyskane w Kwestionariuszu CISS (skale: Styl Skoncentrowany na Zadaniu - SSZ; Styl Skoncentrowany na Emocjach - SSE; Styl Skoncentrowany na Unikaniu - SSU wraz z podskalami: Angażowanie się w Czynności Zastępcze - ACZ i Poszukiwanie Kontaktów Towarzyskich - PKT) oraz w Skali Samooceny Rosenberga SES w grupie ojców dzieci głuchych (średnie)

Style radzenia sobie ze stresem ojców a głuchota i płeć dziecka

Poszukiwano odpowiedzi na pytanie, czy ojcowie dzieci głuchych, a także ojcowie dzieci słyszących stosują różne style radzenia sobie ze stresem ze względu na płeć dziecka. Nie stwierdzono różnic istotnych statystycznie między ojcami dziewczynek i chłopców, zarówno w grupie ojców dzieci głuchych, jak i słyszących.

Style radzenia sobie ze stresem ojców a głuchota i wiek dziecka

W celu odpowiedzi na pytanie, czy style radzenia sobie ze stresem ojców zmieniają się w zależności od wieku dziec$\mathrm{ka}$, wyodrębniono trzy grupy wiekowe dzieci głuchych oraz dzieci słyszących: a) dzieci do 2 lat i 11 miesięcy, b) od 3 lat do 5 lat i 11 miesięcy oraz c) dzieci powyżej 6 lat. Wyniki porównań międzygrupowych (test Kruskala-Wallisa) wskazują na brak istotnych różnic w stylach radzenia sobie ze stresem u ojców dzieci głuchych, a także u ojców dzieci słyszących. Wiek dziecka nie ma znaczenia w odniesieniu do stosowanych przez ojców stylów radzenia sobie ze stresem.

Style radzenia sobie ze stresem ojców dzieci głuchych a czas upływający od momentu diagnozy głuchoty u dziecka

Poddano empirycznej weryfikacji hipotezę o związku stosowanych przez ojców dzieci głuchych stylów radzenia sobie ze stresem i czasem, jaki upłynął od momentu stwierdzenia u dziecka głuchoty (do 2 lat, powyżej 2 lat do 5 lat, powyżej 5 lat). Wyniki analizy statystycznej wskazują, że ojcowie dzieci głuchych stosują podobne style radzenia sobie ze stresem (test Kruskala-Wallisa) niezależnie od tego, jak dużo czasu upłynęło od chwili zdiagnozowania u dziecka głuchoty (Rycina 2).

\section{Samoocena ojców a głuchota dziecka}

Ojcowie dzieci głuchych w zakresie samooceny nie różnią się w sposób istotny od ojców dzieci słyszących o typowym
A

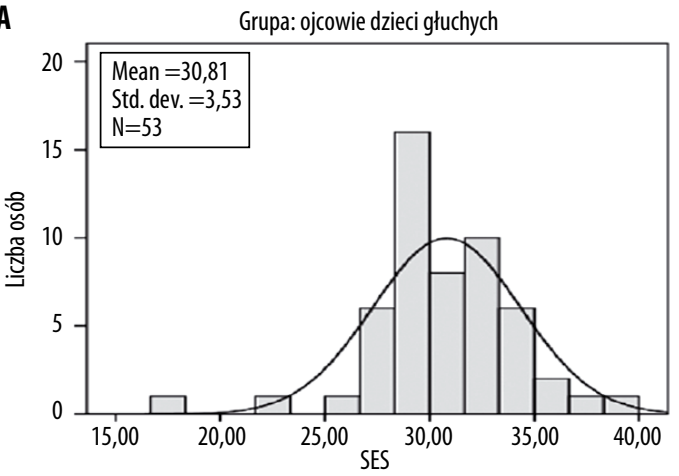

B

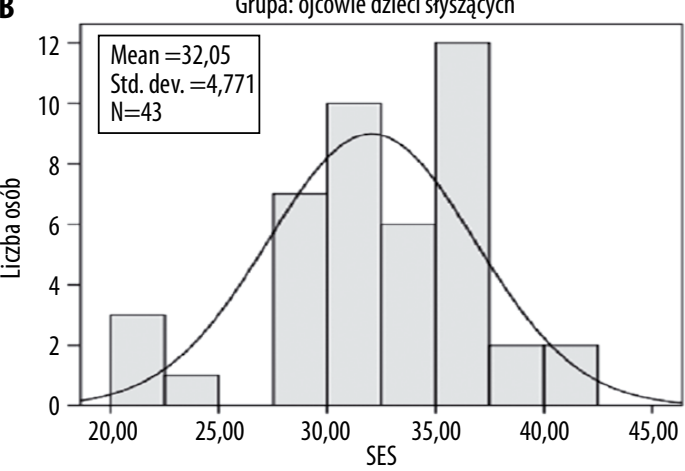

Rycina 3. Rozkład wyników uzyskanych przez ojców dzieci głuchych (A) i ojców dzieci słyszących o prawidłowym rozwoju (B) w Skali Samooceny Rosenberga SES

rozwoju (Ryciny 1, 3A i 3B). Emocjonalny stosunek do siebie i posiadanych możliwości okazał się być podobny w obu badanych grupach ojców.

\section{Samoocena ojców a głuchota, płeć i wiek dziecka}

Samoocena nie różnicuje ojców dzieci głuchych i dzieci słyszących, gdy uwzględnimy płeć (test t-Sudenta) i wiek dziecka (test Kruskala-Wallisa). Ojcowie z obu grup posiadają podobną samoocenę niezależnie od tego, jaką płeć ma ich dziecko i w jakim jest wieku.

Samoocena ojców dzieci głuchych a czas od momentu diagnozy głuchoty u dziecka

Nie istnieje związek między czasem, jaki upłynął od momentu stwierdzenia u dziecka głuchoty (do 2 lat, powyżej 2 lat do 5 lat, powyżej 5 lat) i samooceną ojców. Wyniki analizy statystycznej (test Kruskala-Wallisa) wskazują, iż samoocena ojców dzieci głuchych nie zmienia się w sposób istotny (Rycina 2).

Samoocena a style radzenia sobie ze stresem u ojców dzieci głuchych i słyszących

W celu odpowiedzenia na pytanie, czy na podstawie samooceny ojców dzieci głuchych, a także ojców dzieci słyszących, można przewidywać, jakie stosują style radzenia sobie w sytuacjach stresujących, przeprowadzono analizę regresji liniowej, w której predyktorem była samoocena, a zmiennymi zależnymi style radzenia sobie ze stresem: 
styl skoncentrowany na zadaniu (SSZ), styl skoncentrowany na emocjach (SSE), styl skoncentrowany na unikaniu (SSU) wraz z jego dwiema odmianami: poszukiwaniem kontaktów towarzyskich (PKT) i angażowaniem się w czynności zastępcze (ACZ).

Z przeprowadzonych analiz regresji wynika, że samoocena okazała się być istotnym predyktorem stosowania przez ojców dzieci głuchych oraz ojców dzieci o typowym rozwoju stylu skoncentrowanego na emocjach (SSE). W grupie ojców dzieci głuchych samoocena wyjaśnia $12,4 \%$ wariancji zmienności zmiennej zależnej $(\mathrm{F}(1,48)=7,93 \mathrm{p}=0,007)$, zaś w grupie ojców dzieci słyszących samoocena objaśnia $15,3 \%$ zmienności poziomu SSE $(\mathrm{F}(1,41)=8,6 \mathrm{p}=0,005)$. Wskaźnik beta w obu grupach ma ujemny znak (ojcowie dzieci głuchych - beta $=-0,38$; ojcowie dzieci słyszących - beta $=-0,42)$, co oznacza, że im niższą samoocenę mają ojcowie, tym z większym prawdopodobieństwem w sytuacjach stresujących będą stosować emocjonalny styl radzenia sobie ze stresem, niezależnie od tego, czy ich dziecko słyszy, czy jest głuche.

Okazało się, że samoocena ojców w obu grupach jest istotnym predyktorem stosowania stylu unikającego $\mathrm{w}$ formie angażowania się w czynności zastępcze (ACZ). W przypadku ojców dzieci głuchych samoocena wyjaśnia 11,9\% wariancji zmienności zmiennej zależnej $(\mathrm{F}(1,48)=7,64$ $\mathrm{p}=0,008)$, zaś w grupie ojców dzieci słyszących samoocena objaśnia 8,6\% zmienności poziomu $\mathrm{ACZ}(\mathrm{F}(1,41)=4,94$ $\mathrm{p}=0,032)$. Wskaźniki beta wynoszą: w grupie ojców dzieci głuchych - beta =-0,37; ojcowie dzieci słyszących - beta $=-0,33$, co oznacza, że im niższą samoocenę mają ojcowie, tym bardziej będą skłonni unikać konfrontacji ze stresem, angażując się w czynności zastępcze, niezależnie od tego, czy ich dziecko słyszy, czy jest głuche.

Warto dodać, że związek samooceny z zadaniowym stylem radzenia sobie ze stresem stwierdzony empirycznie u mężczyzn [za: Terelak, 2008; Porębiak, 2007] ujawnił się jedynie w grupie ojców dzieci słyszących (R2=0,13, $\mathrm{F}(1,41)=7,18$; $\mathrm{p}=0,011)$, podczas gdy nie ma związku między samooceną ojców dzieci głuchych a posługiwaniem się przez nich zadaniowym stylem radzenia sobie ze stresem.

\section{Dyskusja wyników}

Celem badań było porównanie psychologicznego funkcjonowania ojców dzieci głuchych z ojcami dzieci o typowym rozwoju w obszarze stylów radzenia sobie ze stresem oraz samooceny. Przyjęto, że głuchota dziecka może mieć modyfikujący wpływ na słyszących ojców w wymienionych sferach ich funkcjonowania. Ojcowie dzieci głuchych doświadczają bowiem traumy wskutek stwierdzenia u ich dziecka głuchoty, a następnie - jak można sądzić - konsekwencji tego faktu. Dlatego też uwzględniono zarówno czas, jaki upłynął od momentu diagnozy u dziecka głuchoty, jak i wiek oraz płeć dziecka.

Otrzymane wyniki badań pokazują, że nie ma różnic w zakresie stylów radzenia sobie ze stresem i samooceny między słyszącymi ojcami dzieci głuchych i ojcami dzieci słyszących o typowym rozwoju - słyszący ojcowie dzieci głuchych są zatem podobni w tych obszarach psychologicznego funkcjonowania pomimo głuchoty dziecka.
Rezultat ten zaskakuje, choć w odniesieniu do stylów radzenia sobie $z$ sytuacjami stresującymi jest zgodny z wynikami badań ojców dzieci z mózgowym porażeniem dziecięcym [Parchomiuk, 2007] czy ojców dzieci z autyzmem [Dąbrowska, Pisula, 2010] porównywanych z ojcami dzieci o prawidłowym rozwoju. Wobec powyżej opisanych rezultatów badań powstaje pytanie, czy ojcowie dzieci głuchych (a także dzieci z inną niepełnosprawnością), którzy zgodzili się na udział w badaniach, są w jakiś sposób ojcami „szczególnymi”? Kolejne z pytań dotyczy tego, co sprawia, że wypadają oni podobnie do ojców dzieci o typowym rozwoju zarówno ze względu na stosowane przez nich style radzenia sobie ze stresem, jak i samoocenę. Należy dodać, że badane zmienne u ojców dzieci głuchych nie wykazują zmienności w czasie: ojcowie wykazują podobieństwo, jeśli chodzi o sposoby radzenia sobie ze stresem i samoocenę, niezależnie od tego, ile czasu upłynęło od momentu stwierdzenia u dziecka głuchoty, jak i niezależnie od wieku dziecka. Także płeć dziecka nie pozostaje w związku z tym, jak ojciec radzi sobie ze stresem (style), jak i z tym, jaka jest jego samoocena. Jak stwierdzono we wcześniejszych badaniach, płeć dziecka odgrywa rolę $\mathrm{w}$ procesie adaptacji ojców do jego niepełnosprawności. Wynika $\mathrm{z}$ nich, że $\mathrm{w}$ relacjach $\mathrm{z}$ córkami z zaburzeniami rozwojowymi trudności ojców ujawniają się w ograniczonym i zrutynizowanym kontakcie, natomiast wobec synów niepełnosprawnych ojcowie wykazują skłonność do skrajnych reakcji: od dużego zaangażowania $\mathrm{w}$ relację $\mathrm{z}$ synem do wycofania się z niej [Bristol, Galagher, 1986; Lamb, Luamann-Billings, 1997; za: Wiktorowicz, 2006].

Jednym z wyjaśnień otrzymanych wyników, wskazujących na brak różnic między ojcami dzieci głuchych i słyszących w stosowanych stylach radzenia sobie ze stresem, jak i posiadanej samoocenie, może być mechanizm zaprzeczania przeżyciom związanym z głuchotą dziecka, uruchamiany przez ojców dzieci głuchych w obronie przed cierpieniem. Zaprzeczanie to pozwala ojcom „normalnie” funkcjonować i realizować rolę ojca zgodnie ze społecznymi oczekiwaniami zapewnienia środków do egzystencji matce i dziecku. Jak zostało już wcześniej wspomniane, w badaniach rodziców dzieci głuchych korzystających z implantu ślimakowego stwierdzono u ojców znacząco większe nasilenie zaprzeczania głuchocie dziecka niż u matek [Anagnostou, Graham, Crocker, 2007].

Podobieństwo ojców dzieci głuchych do ojców dzieci $\mathrm{w}$ wieku przedszkolnym prawidłowo się rozwijających stwierdzono w badaniach nad zaangażowaniem ojców w rolę ojca [Ingber, Most, 2012]. Wspomniane badaczki stawiają hipotezę, że matki dzieci głuchych uniemożliwiają ojcom większe zaangażowanie w pełnienie roli ojca po to, by utrzymać poczucie priorytetowego znaczenia matki dla rozwoju dziecka. Większe (inne?) zaangażowanie ojca wydawać by się mogło spodziewaną reakcją ojców na niepełnosprawność dziecka. Propozycja poszukiwania przyczyn podobieństwa ojców dzieci głuchych do ojców dzieci o typowym rozwoju w psychicznym funkcjonowaniu matek dzieci głuchych i dzieci słyszących otwiera jeszcze inne możliwości rozumienia tego, dlaczego ojcowie dzieci niepełnosprawnych nie modyfikują swojej samooceny, stylów radzenia sobie ze stresem czy zaangażowania $\mathrm{w}$ rolę ojca pomimo doświadczania obiektywnej odmienności dziecka, o której stanowi jego głuchota (niepełnosprawność). 
Z badań cytowanych przez Parchomiuk [Hawkins, Belsky; za: Parchomiuk, 2007] wynika, że zaburzenia w samoocenie ojców pojawiają się wtedy, gdy wzrasta zaangażowanie w obowiązki rodzicielskie, podczas gdy w większości rodzin zaangażowanie ojców dzieci niepełnosprawnych $\mathrm{w}$ pracę zawodową ogranicza zaangażowanie w obowiązki rodzicielskie - co być może „chroni” samoocenę ojców przed negatywnymi przeobrażeniami.

W prezentowanych badaniach okazało się, że ojcowie dzieci głuchych odwołują się do zadaniowego stylu radzenia sobie ze stresem (pomiar deklaratywny) niezależnie od tego, jaka jest ich samoocena. Oznacza to, że są wśród ojców dzieci głuchych tacy ojcowie, którzy podchodzą zadaniowo w konfrontacji z sytuacją stresującą w związku z tym, iż m.in. posiadają wysoką samoocenę (która to, co stwierdzono w badaniach nad mężczyznami z populacji ogólnej, współwystępuje ze stylem skoncentrowanym na zadaniu - za: Terelak, 2008), ale też i tacy ojcowie, którzy w obliczu doświadczanego stresu podejmuja się zadań w obronie swojego „ja” (niska samoocena) - aktywność „zadaniowa" sprzyja wówczas odcinaniu się od przeżyć, zwłaszcza negatywnych, a tym samym ogranicza efektywne radzenie sobie $\mathrm{z}$ problemem lub sytuacją trudną.
Omawiając otrzymane rezultaty badań, należy wziąć także pod uwagę zastosowane narzędzia badawcze: być może nie pozwoliły one na ujawnienie się ewentualnych różnic między ojcami dzieci głuchych i dzieci słyszących w obszarze sposobów radzenia sobie ze stresem i samooceny. Nie jest wykluczone, że głuchota dziecka modyfikuje wybrane aspekty samooceny ojców, jak i tego, jak radzą sobie ze stresem, co nie musi uwidaczniać się w samoocenie globalnej czy stosowanych stylach radzenia sobie z sytuacjami trudnymi. Niewykluczone, że dopiero badania jakościowe ojców dzieci głuchych dotyczące podjętych zagadnień, a także dotarcie do ojców „nieobecnych” w badaniach (a więc $\mathrm{w}$ nich niereprezentowanych), pozwoliłyby na poznanie, jak ojcowie radzą sobie $\mathrm{z}$ głuchotą dziecka, a także czy ich „podobieństwo” do ojców dzieci o typowym rozwoju wynika $\mathrm{z}$ obrony przed cierpieniem, adaptacji do głuchoty dziecka, niedoskonałości metodologicznych badań, czy jest odpowiedzią na potrzeby matek dzieci głuchych (niepełnosprawnych) związane z realizacją ich macierzyńskich funkcji (Stern, 1995). Konieczne są dalsze badania nad ojcami dzieci głuchych w wielu obszarach ich psychicznego funkcjonowania, włączając w to matki i ich dzieci (głuche), którym ojciec ma za zadanie zapewnić optymalne warunki fizycznej i psychicznej egzystencji i rozwoju.

\section{Piśmiennictwo:}

1. Anagnostou F., Graham J., Crocker S.: A preliminary study looking at parental emotions following cochlear implantation. Cochlear Implants Int, 2007; 8: 68-86

2. Asberg K.K., Vogel J.J., Bowers C.A.: Exploring correlates and predictors of stress in parents of children who are deaf. Implication of perceived social support and mode of communication. J Child Family Studies, 2008; 17: 486-99

3. Dąbrowska A., Pisula E.: Parenting stress and coping styles in mothers and fathers of pre-school children with autism and Down syndrome. J Intell Disabil Res, 2010; 54(3): 266-80

4. Dzwonkowska I., Lachowicz-Tabaczek K., Łaguna M.: Samoocena i jej pomiar. Polska adaptacja skali SES M. Rosenberga. Warszawa: Pracownia Testów Psychologicznych, 2008

5. Endler N.S., Parker J.D.A.: Assessment of multidimensional coping: task, emotion and avoidance strategies. Psychological Assessment, 1994; 6: 50-60

6. Endler N.S., Parker J.D.A.: Multidimensional assessment of coping. A critical valuation. J Pers Soc Psychol, 1990; 58(5): $844-54$

7. Hatchett G.T., Park H.L.: Relationships among optimism, coping styles, psychopathology, and counseling outcome. Pers Indiv Differ, 2004; 36: 1755-69

8. Ingber S., Most T.: Father's involvement in preschool programs for children with and without hearing loss. Am Ann Deaf, 2012; 157(3): 276-88

9. Jackson C.W.: Family supports and resources for parents of children who are deaf or hard of hearing. Am Ann Deaf, 2011; 156(4): 343-62

10. Kobosko J. Parenting a deaf child - how hearing parents cope with the stress of having deaf children. JHS, 2011; 1(3): 39-44

11. Kurtzer-White, E., Luterman, D.: Families and children with hearing loss. Grief and coping. Ment Retard Dev Disabil Res Rev, 2003; 9: 232-35

12. Lis-Turlejska M.: Traumatyczny stres. Koncepcje i badania. Warszawa: Wydawnictwo Instytutu Psychologii PAN, 1998
13. Margalit M., Raviv A., Ankonina D.: Coping and coherence among parents with disabled children. J Clin Child Psychol, 1992; 2(3): 202-9

14. McWilliams L.A., Cox B.J., Enns M.W.: Use of the Coping Inventory for Stressful Situations in a clinically depressed sample. Factor structure, personality correlates, and prediction of distress. J Clin Psychol, 2003; 59: 423-37

15. Ogińska-Bulik N., Juczyński Z.: Osobowość, stres a zdrowie. Warszawa: Difin, 2010

16. Olsson M.B., Hwang C.P.: Depression in mothers and fathers of children with intellectual disability. J Intell Disabil Res, 2001; 45(6): 535-43

17. Parchomiuk M.: Rodzice dzieci z mózgowym porażeniem dziecięcym wobec sytuacji trudnych. Lublin: UMCS, 2007

18. Phares V., Lopez E., Fields S., Kamboukos D., Duhig, A.M.: Are fathers involved in pediatric psychology research and treatment? J Pediatr Psychol, 2005; 30(8): 631-43

19. Pisula E.: Rodzice i rodzeństwo dzieci z zaburzeniami rozwoju. Warszawa: Wydawnictwa Uniwersytetu Warszawskiego, 2007

20. Sekułowicz M., Sipiorski P.: Style i strategie radzenia sobie rodziców dzieci z niepełnosprawnością. (W:) Ziółkowska T., Konopska L. (red.) W kręgu niepełnosprawności. Teoretyczne i praktyczne aspekty poszukiwań w pedagogice specjalnej. Szczecin: Uniwersytet Szczeciński, Wydział Humanistyczny, 2009; 443-60

21. Stern D.N.: The motherhood constellation. A unified view of parent infant psychotherapy. New York: Basic Books, 1995

22. Strelau J., Jaworowska A., Wrześniewski K., Szczepaniak P.: CISS - Kwestionariusz Radzenia sobie w Sytuacjach Stresowych. Warszawa: Pracownia Testów Psychologicznych PTP, 2009

23. Terelak J.F.: Człowiek i stres. Koncepcje, źródła, reakcje, radzenie sobie, modyfikatory. Warszawa-Bydgoszcz: Oficyna Wydawnicza Branta, 2008 
24. Wiktorowicz R.: Uwarunkowania psychologicznej adaptacji ojca do problemów rozwojowych dziecka. Przegląd literatury. Nowiny Psychologiczne, 2006; 3: 5-19

25. Zaczyńska M.: Tożsamość ojcowska ojców dziecka głuchego. Niepublikowana praca magisterska. Warszawa: Wydział Psychologii, Uniwersytet Warszawski, 1999
26. Zalewska M.: Dziecko w autoportrecie z zamalowaną twarzą. Psychiczne mechanizmy zaburzeń rozwoju tożsamości dziecka głuchego i dziecka z opóźnionym rozwojem mowy. Warszawa: J. Santorski i CO Wydawnictwo, 1998

27. Zalewska M.: Psychologiczne aspekty stwierdzenia głuchoty u dziecka. (W:) Rola J. (red.). Wybrane problemy psychologicznej diagnozy zaburzeń rozwoju dzieci. Warszawa: Wydawnictwo WSPS, 1998; 177-86 